\title{
RELIGIOSITY AMONG WORKING CLASS \\ (A Study of the implementation of Act No. 13 of 2003 on Manpower in The Rights to Perform Religious Obligations)
}

\author{
Ikhwan Aulia Fatahillah ${ }^{1^{*}}$ \\ Dadan Anugrah² \\ ${ }^{1}$ Law Study Program UIN Sunan Gunung Djati Bandung \\ 2 Islamic Broadcasting and Communication Study Program UIN Sunan Gunung Djati Bandung \\ *Corresponding Author, Email: ikhwanaf@uinsgd.ac.id
}

\begin{abstract}
The implementation of Act No. 13 of 2003 on Manpower is intriguing to discuss since companies often violate and are apathetic in the right to act for employees' religious beliefs. The limited facilities of worship in the workplace also represents the commitment engagement of the company towards promulgated regulations which is still not implemented.

The purpose of this study is to provide the more specified description and understanding towards the religiosity and implementation of Act No. 13 of 2003 on Manpower concerning The Rights to Perform Religious Obligations for Laborers. This study, which focuses on the religiosity of this worker class, took two different places, namely in Bekasi Regency and Subang Regency.

This study uses qualitative methods which enables to reveal the actual circumstances. More specifically, qualitative research can be identified by the aim of research that seeks to understand the manifestation that does not require quantification--or because this manifestation is unable to be accurately measured. In relation to the method, the data collecting techniques are as follows: (1) nonparticipant observation and (2) in-depth interviews. While the data analysis starts from (1) data reduction, (2) data presentation, and (3) drawing conclusions.

By this study, the authors concluded: (1) companies that have become research object in Bekasi and Subang District have provided worship facilities and infrastructure as regulated in Act N. 13 of 2003 on Manpower in the Respect to Perform Religious Obligations. On the other hand, the workers still look forward some improvements on quality and quantity of worship facilities to emerge conveniences in performing worship; and (2) in general, the religiosity among working class is found at an average level. In other words, the workers truly believe in God (Allah) with common knowledge about faith. They also perform religious practices as the evidence of the faith itself and as proof of obedience to God. Besides carrying out the orders of religion (worship), the workers also put some expectations on the reward as the way to accomplish the glory on Earth and afterlife. However, the workers realize that the worship carried out would not come to a subjective perspective (their dialogue with supernatural powers, Allah). The workers also attempt to make religion as the basis of all actions as they consider the consequences of the life on Earth for the afterlife.
\end{abstract}

Keywords: Religiosity, Manpower, Religious obligations.

\section{A. INTRODUCTION}

In some countries, such as Indonesia, industrialization is a necessity. The indicators of developing countries or even developed countries can be identified through the performance of the country in taking up the industrial sector for social prosperity. Prosperity is the "core" in which the state stands to provide economic preservation for its people. Prosperity is the essence of moral and constitutional messages as stated in the Introduction of The 
1945 Constitution. The state's role is to ensure prosperity through various policies, regulations, and actions that absolutely prioritize the people.

Industrialization and the economy can be depicted as a coin with its both sides. Industrialization engages and accelerates the rate of economic growth as the foundation of prosperity. While industrialization has a considerable social impact, especially on social polarization, social mobility, work relations, the level of religiosity (diversity) of workers and so on. It shows that recently there is no country able to turn away from the industrialization process with various impacts and consequences as the power of development.

In Indonesia, the industrialization process has begun since The New Order until today's The Reformation Era. Industrialization is often interpreted as the process of a foreign capital that builds large working capacity factories which enable to involve thousands of employees. Through an economic perspective, it shows that there are several advantages from industrialization, for instance; firstly, industrialization increases national income which has a significant impact on people's prosperity as well; Secondly, industrialization also provides abundant manpower so that it can hire a number of laborers or workers (productive age) in both the industrial sector and other sectors such as the trading sector. Additionally, for the third advantage, industrialization will increase national competitiveness so that the state has a competitive advantage based on comparative advantage by referring to the development of industrial clusters; thus, a solid and balanced industrial structure is created. Fourthly, Industrialization also maintains the professionalism for business actors and trade institutions so that the trade activities of goods and services in the country continuously develop. Fifthly, industrialization presents a conducive business circumstance by applying market mechanisms without distortion, as well as ensuring consumer preservation; therefore, it also provides consumers understanding of their rights and responsibility in the means of quality, business, and measure orders. Lastly, industrialization engages the increasing of professionalism among human resources, mastering the use of technology and innovation, and fulfilling the qualifications: safety, health and environmental local and international standards both nationally and internationally.

Referring to the six points above, industrialization obviously provides many benefits for the social development, nation, and state in terms of economics and utilization of human resources. In comparison to other countries, Indonesia also confronts a crucial problem in taking up well-educated and less educated workers. These labor issues deal with more complicated challenges as Indonesia is currently involved the Asean Economic Community (AEC) [1]. The AEC is purposed to compromise a better future that Indonesian workers are able to be a part of overseas activities; nevertheless, it triggers a threat in which competition for manpower must compete with workers from neighboring countries.

Bekasi Regency and Subang Regency are two regions which are currently part of the national industrialization area. In the two regencies, there stand national and multi-national factories which hire thousands of workers. The hiring of labor by companies has a positive impact on improving the prosperity of the community, both local communities, and urban communities. In macro terms, the stability of an area can be identified as high level as long as the economy is also stable. In a sociological perspective, a community which is more dominated by unemployed may cause a social insecurity and problem.

The presence of industrialization represented in the form of factories by hiring a large number of workers, on the one hand, is able to provide for the community; but on the other hand, it emerges various problems that are also complicated. As an example, the working class has a strict working hour derived from company system that prioritizes effectiveness and efficiency as well as very high work discipline. As the result, workers at this class transformed into a highly controlled "robot" to work a high-quality production. On the other hand, the strict work procedure affects the implementation of ritual worship as it is obligated to every religious person.

Applying the religious regulations does not only reflect a personal piety but also has an impact on social piety. A person who obeys the law (the religious regulations) must be able to apply for himself regarding the person's religious values. Moreover, high religiosity qualitatively will have a positive impact on performance in the workplace. 
Indeed, every human including the workers has the right to safely worship as an embodied values within Pancasila, The 1945 Constitution [2], and Act No. 13 of 2003 on Manpower in the Right to Perform Religious Obligations. The right to perform the prayers is a basic right guaranteed by The 1945 Constitution as stated in Article 29.

The topic on the implementation of Act No. 13 of 2003 on Manpower is compelling as companies often violate and are apathetic in employees' right to perform their religious beliefs. The limited place of worship at work is also a form of how the company does not have a commitment to the implementation of the rules that have been promulgated.

Therefore, this study on the religiosity of these workers has chosen two different places, namely in Bekasi regency and Subang regency. The considerations in determining this place are: First, Bekasi Regency is a district that has long been an industrial area in West Java. Therefore, the dynamics of the implementation of regulations regarding labor is very likely to attract and produce discourse involving many parties. Second, Subang Regency can be said to be a district that has not been used as an industrial area for too long. At present, there are large-scale factories in Subang district involving thousands of workers (workers) from various places, especially in West Java.

\section{B. METHOD}

This study used a constructive paradigm, where reality basically was built or constructed through certain ways as expected. To maintain a harmony within a company, including guaranteeing the rights in performing religious obligations, certain actions must be performed consciously. Realities expected were presented and constructed through various considerations in accordance with the ideals desired. Implementation of Act No. 13 of 2003 on Labor in the Rights to Perform Religious Obligations was considered as a part of the social construction. In the context of religion, construction occurred during the implementation of social worship (Ghaer Mahdlah). Worship performed did not have a standard pattern, as in fundamental (mahdlah) worship. Worship in the form of social activity was committed entirely to humans based on religious values. Method, techniques, and implementation of worship were given entirely to humans.

This study used a qualitative method which aimed to reveal the reality that was actually experienced by human beings. Significant indicators of a qualitative research were identified from the purpose of the research that sought to understand causes in such a way that did not require quantification, or because these causes or symptoms did not allow to be accurately measured. Additionally, the qualitative of this study were indicated (1) based on qualitative observations which were contradicted a quantitative research; (2) quality referred to the natural aspect contradicted quantum or number; (3) qualitative research was defined as non-calculated research.

The data were collected through non-participant observation and in-depth interviews. On the other hand, data analysis was performed continuously during the research, starting from the formulation of the problem to the writing of the results of the study. According to Mulyana, in a subjective perspective (qualitative), data analysis was done inductively; continuous from the beginning to the end; observing models, patterns or themes [3]. The data analysis process must begin with examining all available data from various sources, the data were then read, studied, and reviewed ${ }^{[4]}$.For the purposes of this study, the data analysis used referred to the interactive analysis techniques of Miles and Huberman. This technique was called interactive model which basically consisted of three components, namely data reduction ( data reduction), data presentation ( data display ), and drawing and verifying conclusions.

\section{RESULTS AND DISCUSSION}


The results of this study are divided into two parts: the first part relates to the Application of Act No. 13 of 2003 on Manpower In the Rights to Perform Religious Obligations and the second part relates to religiosity with its various dimension.

The data on the Application of Act No. 13 of 2003 on Manpower in the Rights to Perform Religious Obligations are obtained through observation and interviews. Observation data show that all companies (factories) observed have implemented Act No. 13 concerning Manpower by building worship facilities such as mosques or halls, including complementary equipment.

Within companies with a large number of employees built a representative mosque to accommodate the implementation of worship such as Friday prayers. While in some parts of buildings, there is also a prayer hall that can accommodate a limited number of people. On weekdays, the prayer service is carried out alternately. Generally, the company has a mechanism to maintain worship and the work system; it has been arranged in such a way, hence the worship is able to perform well and regularly.

The management expects that by providing the facilities, it can affect the responsibility of the workers due to the workers are religiously devoted. Since religion teaches about responsibility, religious workers believe that the work itself is a form of worship [5].

In order to emphasize the understanding of the availability of worship facilities in the company, a checklist-form questionnaire is disseminated as follows:

Table 1.

Research Instrument

The proposition of Worship Facilities' Availability at AHM Ltd. (Astra Honda Motor).

\begin{tabular}{|c|l|c|c|}
\hline NO & \multicolumn{1}{|c|}{ PLACE OF WORSHIP } & TOTAL & APPROPRIATENESS \\
\hline 1. & Mosque & 1 & Proper \\
\hline 2. & Musala (Prayer Hall) & 6 & Proper \\
\hline 3. & Ablution Room & 6 & Proper \\
\hline 4. & Mukena (Women's Prayer Dresses) & - & - \\
\hline 5. & Sarong (Men's Prayer Sheath) & - & - \\
\hline 6. & Prayer Rug & 6 & Proper \\
\hline 7. & Slippers & 30 & Proper \\
\hline 8. & The Quran & 24 & Proper \\
\hline 9. & Calligraphy Decoration & 12 & Proper \\
\hline 10. & Prayer-Time Clock & 5 & Proper \\
\hline 11. & Microphone and Speaker & 2 & Proper \\
\hline 12. & Carpet & 6 & Proper \\
\hline
\end{tabular}

Table 2.

Research Instrument 
The proposition of Worship Facilities' Availability at Indofood Sukses Makmur Ltd. PLC

\begin{tabular}{|c|l|c|c|}
\hline NO. & \multicolumn{1}{|c|}{ PLACE OF WORSHIP } & TOTAL & APPROPRIATENESS \\
\hline 1. & Mosque & 1 & Proper \\
\hline 2. & Musala (Prayer Hall) & 1 & Proper \\
\hline 3. & Ablution Room & 5 & Proper \\
\hline 4. & Mukena (Women's Prayer Dresses) & More than 10 & Proper \\
\hline 5. & Sarong (Men's Prayer Sheath) & More than 10 & Proper \\
\hline 6. & Prayer Rug & More than 10 & Proper \\
\hline 7. & Slippers & More than 10 & Proper \\
\hline 8. & The Quran & More than 10 & Proper \\
\hline 9. & Calligraphy Decoration & 5 & Proper \\
\hline 10. & Prayer-Time Clock & 1 set & Proper \\
\hline 3. & Microphone and Speaker & 1 set & Proper \\
\hline 12. & Carpet & Available & Proper \\
\hline
\end{tabular}

The two tables above show that the company provides proper facilities for the workers to perform worship. Additionally, the availability and appropriateness of the worship facilities represent the company commitment towards the workers in performing worship. Companies can also be said to prioritize the improvement of workers religiosity in which the improvement allows them to dedicate to their religion.

In most of the large-scale companies, the facilities and infrastructure of worship are sufficient. However, there are also "less comfortable" term among the rest of the companies, frequently caused by the worship facilities for women. One of the female informants explains about her convenience, for example from a small prayer hall and the available facilities for wudlu (ablution) and mukena (prayer dresses) ${ }^{[6]}$.

However, the facilities of worship in several companies observed generally are sufficient. It can be said that the company has carried out its obligations in providing religious facilities to guarantee the rights of the working class. Thus it can be concluded that Act No. 13 of 2003 on Labor has been well established by the company. Meanwhile, for the unavailable facilities, most of them have no significant problems that may affect the rights of workers in performing worship. The workers also claim that they look forward to the continuous improvement of worship facilities.

The worship is not only related to facilities in the company but also related to the time given by the company, especially the time to perform five daily prayer services. The law instructs that companies must provide flexibility for their workers to perform their respective religious shari'a (regulations).

Additionally, one of the informants in Bekasi Regency conveys that the company gives time to perform daily prayer for approximately thirty minutes, except on Friday (Friday prayer). The informant then says that the workers need to use the time properly so that they are also able to take a break after 
performing worship. The availability of facilities such as mosques, prayer hall, and representative ablution rooms can help the workers efficiently take their time; therefore, the informant assumes that his clothing is clean so that he can immediately perform the prayer ${ }^{[7]}$.

\section{The Dimension of Religious Beliefs}

The dimension of religious belief is the most significant part of actualizing the religion in the concrete realm. Amaliyah or the application of religion must be believed as the form of worship Allah SWT. The dimension of religious belief is built on the faith in the presence of The Most Great spirit, Allah SWT, as the foundation of every little activity of mankind.

Every religion, especially Islam, is based on beliefs which in religious definition, beliefs are defined as faith. The word "faith" is from Arabic which is defined as to believe. While according to the term, the notion of faith is to believe by the heart, spoken by mouth, and applied by actions (deeds). Thus, the notion of faith in God is to believe by the heart that God really exists with all of His majesty and perfection, then the faith is spoken, and is proven by real deeds.

Therefore, someone can be said to be an ideal believer (mukmin) as long as fulfilling the three elements of the faith above. If someone acknowledges in his heart about the existence of God but is not stated in oral and proven by deeds, then that person cannot be said to be a perfect believer. Because the three elements of the faith are a unified and inseparable whole.

The result of interviews with a number of informants shows that the workers are culturally religious (obedient), even though with the consideration that they still need to be improved. In the context of strengthening the faith, humans are demanded to deepen their knowledge about their religion. ${ }^{[8]}$

For this dimension of belief, more than ten informants are asked and result in the same description that they perform the Shari'a based on their belief in Allah SWT. Even though they are not well educated, they give a similar answer when dealing with questions about God, namely believing in God as The Decisive spirit. As a form of faith in Allah, they continue to carry out religious Shari'a such as praying in the middle of work with approximately thirty minutes. Once the researchers observed when entering the dawn they flocked to the prayer place interchangeably. From their faces, they looked tired but still carried out worship services with joy.

In addition, the result shows that their level of belief in God is excellent through verbal indicators as proven by the results of interviews and proven through observations. Within the ideal limit, the workers understand the dimension of this belief which places God as the thing to be worshiped (Tawhid). Specifically, Tawhid can be associated with monotheism. Tawhid (Oneness) is basically the process of liberation from various idols that grow and develop in the culture of society, and only place God as an entity that must be worshiped. What is meant here is to believe that God is one. While in terms of the science of Tawheed is the science that discusses all beliefs taken from the postulates of the postulates of beliefs and laws in Islam, including the law to entrust Allah is one. However, for those who do not believe in the oneness of Allah or deny the things that are the basis of the knowledge of monotheism, then they are categorized as not Muslim and known as infidels. Likewise, if a Muslim swaps the belief in the oneness of Allah, then the person is considered the same as infidel [9].

\section{The Dimension of Religious Practice}

The second dimension of religiosity is a religious practice. This dimension includes worship, obedience, and things people do to show commitment to their religion. These religious practices include two things, namely ritual, and obedience. The dimension of religious practice is a logical continuation of the belief 
in God as reflected in the dimension of belief. A person may not possible to actualize religious knowledge without excellently devoting God.

In addition to the interview section, the questions are obtained from some basic questions to propagate to deeper questions, for example: "do they perform religious law (obligatory worship and other worship) in daily life", and so on. One of the informants responses actively in his house between breaks at dusk. While accompanied by a cup of coffee and snacks, the conversation is focused on aspects of religious practice in sub obedience. The results of the study can describe two things: First, workers are generally individuals who are obedient in carrying out religious practices, such as prayer. They understand very well that one of the obligations of a religious person is to perform God's commands under any circumstances. Second, even though they are aware of their obligations as Muslims, they must carry out religious principles as a whole, but in fact, there are principles which are still "violated". This violated meaning does not refer their ignorance, but it is unconsciously missed. In the understanding of researchers, their level of religiosity in the dimension of religious practice still needs to be improved [10].

On the other hand, they realize the significance of worshipping God. Worship is proof of faith, while faith is the heart of religion. In the case that a worker is unable to perform worship ideally (a hundred percent performance), the worker may not be categorized as an "infidel" due to the person's unconscious negligence. The workers' faith and the implementation of their worship can still be improved to reach its peak. Humans are basically dynamic, thus the current issue which is unimplemented may further be fully performed.

\section{The dimension of Religious Experience}

This dimension maintains and takes into account the fact that all religions contain certain goalsalthough it is not appropriate to say that a person who has an excellent religious knowledge becomes to attain subjective knowledge and regarding directly the final actuality (the fact that the person will have a contact with supernatural powers).

This dimension is relatively difficult to be parsed to the factual perspective of religion. High-level religious experience is in a phase where one is able to "see" the Holy Spirit, and this is only possible by Sufis. Nevertheless, this study provides questions that are able to reveal the dimension of religious experience.

At the most basic level, all informants agree that the religion they believe contains the expectation of the Judgement day, the rewards and punishment for good and wrong, assigning God as an entity to complain, and so on. They also firmly believe in the Judgement day whether they do good deeds and perform religious orders on Earth, they will be multiply rewarded in the afterlife.

The data obtained provide a description that in fact, the workers put high expectations on religion both for life on Earth and in the afterlife. They generally acknowledge that there is a "beautiful" reward when trying hard in performing God's commands. In this aspect, religion absolutely contains expectations through the rituals to carry out. Religion guarantees happiness offers to see true pleasure.

On the other hand, the dimension of religious experience is not only related to expectations of God's reward in accordance with the level of worship but furthermore religion "promises" to its believers to be able to "meet" or "dialogue" directly with God. Probably in this sub-dimension, it is hardly experienced but by a person with the high excellence of religion such as Sufi and Ulema.

Some excerpts from this interview describe the questions related to the dimension of religious experience at the stage of subjective knowledge. The subjective knowledge interpreted is how a believer knowledge is obtained directly from God without intercession. 
Referring to the results of the interview, there are two things can be stated: Firstly, they generally realize that there are hopes or desires that underlie their manner toward worship. They generally expect heaven as a reward for all the worship they perform. It can be said as a common case since it can be performed by some believers. This expectation also provides a description of the extent and depth of what their religious knowledge is. Their knowledge obtained from the Ustadz around (Muslim teacher) is limited to the way of ritual and the common topic about what is allowed and forbidden.

Secondly, all informants show their pessimistic since it is a long way to earn the subjective knowledge. They generally argue that subjective knowledge is only possessed by people whose level of faith and servitude are very excellent, probably even those who have reached the level of zuhud. This study observes outwardly, that they do not have "signs" that can provide them subjective knowledge [11].

Related to the observations, the workers perform religious rules but do not reach the disclosure of subjective knowledge. They only try to worship, perform ritualism and expect the rewards. To achieve subjective knowledge requires understanding and practicing religion beyond common believers.

\section{The dimension of Religious Knowledge}

This dimension refers to the expectation that religious persons have some knowledge about the basics of beliefs, rites, scriptures, and traditions. The comparison of worship quality between those who have religious knowledge and those who do not is significant. Ideally, someone who embraces a religious belief, for example, a Muslim, equips himself/herself with various religious knowledge so that the method and practices of worship become a strong foundation. The dimension of knowledge also provides a strong characteristic for someone capable of understanding the teachings of which are often complicated. There are teachings of the religion that both can be understood through the rational domain and that are simply believed.

The knowledge of religion starts from basic things, such as monotheism, pillars of faith, pillars of Islam, ways of worship, and other aspects that are not clearly stated. The dimension of religious knowledge can be obtained through various ways, such as self-taught by reading the Quran, Islamic books, participating in various recitations, participating in study groups, or just having a dialogue (discussion) with the Ustadz (teacher) nearby in which in this context religion is studied.

Some of the interview results provide a description that they lack religious knowledge. They generally have limited knowledge which is basic and only related to mahdhah worship.This finding can be rationalized on two things: Firstly, they actually do not have much spare time to learn or deepen religious knowledge. They are only preoccupied with work as laborers and family members, and the rest is used for taking a rest. Based on this study's observation, since they work during the day, the afternoon and night time are used for rest and family.

Secondly, up to this point, the company has not provided time for workers (laborers) to hold recitals or religious lessons. The company acts pragmatically which means the company only prioritizes profit by "pressing" workers to work according to SOP (standard operating procedures). However, religiosity is very significant to strengthen workers' personality in which it may affect the work performed for the company [12].

\section{The Dimension of Application (Consequences)}

This dimension refers to the identification of the consequences of one's religious beliefs, practices, experiences, and knowledge in a timeline. It means how religion becomes a part of daily behavior or the functionalization in the practise region. 
Generally, persons who perform a religion completely (kaaffah) are believed to reflect their daily activities. The Daily activity or behavior can be said to be the manifestation (consequence) of the religious beliefs and practices. Religious persons are considered to be more careful hence all their behavior is guided by religious teachings-although the frequent cases of faith, knowledge, and religious appreciation are disconnected in the praxis area. In the concept of social psychology, this phenomenon can be identified as a split personality.

Persons who are religious but they still do disobedience or their behavior do not reflect the religious value are identified as the persons with multiple personalities. They often go to the mosque, attend the recitation, can read the Quran well, but their actions and behavior are far from the teachings of religion. Ideally, diversity does not only create personal piety (vertical) but also must be able to create social piety (horizontal). In fact, the essence of religion is seen and manifested in association with family and society.

In the midst of life that shows various crimes among the elite, there is still the mind of a laborer who enlightens and soothes. As the saying goes, the goodness comes from anywhere in any time, as well as crime can come from anyone in anytime. The informants have been able to actualize and function the principles of his religion as an ideology and behavior. This is what is meant by the dimension of consequences (religious practice) that manifests and grows in real life. It also signifies that the lowerclass community is away from the issue of corruption [13].

The Informants are also able to analytically compare the dimension of religious consequences in the social area, namely comparing workers with the behavior of politicians and state officials. This indicates that they generally follow the latest developments and situations through the mass media. This condition is considered excellent to provide intelligence for workers who are often associated with lower-class community-also considered as stomach-oriented people.

\section{Discussion}

In this section, this study elaborates the research data and attempt to understand then draw conclusions. In related to the findings, this study also synthesizes and triangulates data so that the data produced can be academically accounted.

As one of the developing countries, Indonesia is the destination of foreign investment (PMA) which is engaged in national and international scale industries. Apart from the problem of industrialization that cannot be resolved, this study focuses on aspects of workers' religiosity and the Application of Labor Act No. 13 of 2003 on Manpower in the Rights to Perform Religious Obligations. This law explicitly speaks of Employers having to provide sufficient opportunities for workers/laborers to carry out worship required by their religion. At the operational level, Act No. 13 on Manpower is explained as follows:

What is meant by sufficient opportunity is to provide a place that allows workers to perform their worship properly, in accordance with the conditions and capabilities of the company.

Based on the Act and its explanation, the company is required to provide facilities and infrastructure for worship for all employees such as mosques, prayer rooms, mukena, sarongs, prayer mats, ablution places, and others. In addition, the company is also obliged to provide time for employees to perform services such as daily prayers and prayers on Friday.

The data collected are narrowed as to describe relevant findings and understanding regarding the Application of Act No. 13 of 2003 on Manpower in the Rights to Perform Religious Obligations and their dimension of religiosity.In general, the company has carried out its obligations in providing worship 
facilities and infrastructure even though some companies still obtain data that still does not meet the comfort level.

Towards the dimension of religious belief, this study succeeds in collecting data that they (the workers) generally believe in the existence of Allah as the One to believe and as a foundation of idealism. The workers understand that the belief in God is their foundation in religion which has an impact on personal piety and social piety. Islam teaches that perfection of faith is not only manifested through a series of ritual worship ( vertical ) but also manifested through social piety ( horizontal ).

In the dimension of religious practice, this study provides two insights into the behavior of religious practices of the workers. First, workers are able and as strong as their personnel to carry out their obligations in worship, even if in very limited time. Second, religious practice is a manifestation of obedience to God which is reflected in daily life by making religion the starting point for all activities.

Additionally, in the experience part, the workers in carrying out religious orders (worship) have hopes in the form of God's help both in the world and the end. Religion provides coolness when various difficulties in life hit themselves and their families. Religion and all its rituals bring hope for life later in the hereafter to get good with the guarantee of heaven. Whereas on the other hand, workers are aware that the diversity they are doing now will not be able to reach subjective knowledge (to dialogue with supernatural powers).

In the dimension of religious knowledge, this study is able to provide a description that in general, the religious knowledge of the workers is at an average or normal level. It signifies their religious knowledge is only limited to ritual worship and has not yet reached the depths of the religion itself. Their religious knowledge is mostly obtained from mosques around their homes and through the mass media. Although they realize that religious knowledge is very significant to improve the way they worship and increase their faith in God, the company has not reached the implementation of spiritual guidance such as recitation and religious scientific studies.

In the dimension of practice (labor), the workers attempt to behave in accordance with the religious guidance and principles. The workers also claim that they realize of every action they do has consequences that affect the achievement of happiness on Earth and afterlife. This awareness also engages them to work harder with the expectation of a reward from God.

\section{CONCLUSION}

Religiosity is a significant part of human existence which is reflected in five dimensions of religion, namely beliefs, practices, experiences, knowledge, and application (consequences). Based on the results of the study, it can be concluded that:

Firstly, the companies observed in Bekasi and Subang Districts have provided religious advice and infrastructure as regulated in Act No. 13 of 2003 on Manpower in the Rights to Perform Religious Obligations. On the other hand, workers still look forward to some improvements on quality and quantity of worship facilities so that they can perform worship more comfortably; and

Secondly, the religiosity of workers generally is at the mid or average level. It can also be said that the workers truly believe in Allah with low-level religious knowledge. They also apply religious practices as evidence of the faith itself and as proof of obedience to God. The workers in performing the orders of religion (worship) are associated with expectations of reward (consequences) due to achieving happiness for the afterlife. However, the workers consider that the worship performed is unable to reach the subjective knowledge (the dialogue with supernatural power, namely Allah). The workers also try to make religion as the basis of all actions since every action has its own consequences for life on Earth and in the afterlife. 


\section{REFERENCES}

Afif, Abdullah, 1994. Tauhid Dalam Pendekatan Fisika Modern. Surabaya: Al-Ikhlas.

Ahmad Nuar Dwiyarno. (2008). Takwa dan Tawakkal kepada-Nya. (online), (http://spesialistorch.com/content/view/109/29/, diakses 16 Agustus 2010).

Ali, Muhammad Daud. 2006. Pendidikan Agama Islam. Jakarta: PT. RajaGrafindo Persada.

Al-Qaradhawi, Yusuf.1999. Reposisi Islam.Terjemahan oleh Muhammad Arif Rahman. 2001. Jakarta: Al Mawardi Prima.

Ancok, Djamaludin dan Fuat Nashori Suroso, 1995. Psikologi Islami. Yogyakarta: Pustaka Pelajar.

Asuru, Arsidik Dkk. 1997. Pendidikan Agama Islam. Kendari: Universitas Haluoleo.

Badudu-Zain, 1994.Kamus Umum bahasa Indonesia. Jakarta: Sinarhaparan.

Baharuddin dan Mulyono, 2008.Psikologi Agama Dalam Perspektif Islam.Malang: UIN-Malang Press.

Bahreisy, Salim, tt. Terjemahan Al-Hikam, Pendekatan Abdi Pada Khaliqnya. Surabaya: balai Buku.

Brannen, Julia, 2002. Memandu Metode Penelitian Kualitatif dan Kuantitatif. Yogyakarta: Pustaka Pelajar.

Bungin, Burhan (ed), 2006. Metode Penelitian Kualitatif: Aktualisasi Metodologis Ke Arah Ragam Varian Kontemporer. Jakarta: Rajawali Press.

Bungin, Burhan, 2003. Analisis Data Penelitian Kualitatif. Jakarta: Rajawali Press.

Departeman Pendidikan Nasional, 2014.Kamus Besar Bahasa Indonesia Pusat Bahasa, edisi keempat. Jakarta: Gramedia Pustaka Utama.

Djaelani, Abdul Qodir. 1996. Perjuangan Ideologi Islam di Indonesia. Jakarta: Pedoman Ilmu Jaya.

Effendy, Onong Uchjana, 1993. Human Relations \& Public Relations dalam Manajemen.Alumni Bandung.

Fuad Nashori, Fuad dan Rochmy Diana Mucharam, 2002. Mengembangkan Kreativitas dalam Perspektif Psikologi Islami.Yogyakarta: Menara Kudus.

Ghazali, A. Muchtar dan Abdul Majid, 2014.Pendidikan Pancasila dan Kewarganegaraan.Bandung: interes.

Iskandar, Arief B. 2010. Tetralogi Dasar Islam. Bogor: Al-Azhar Press.

Kahmad, Kahmad, 2000. Sosiologi Agama. Bandung: Remaja Rosdakarya.

Khalid, Amru, 2013. Ibadah Sepenuh Hati. Solo: Aqwam Media Profetika.

Kuswarno, Engkus, 2009. Fenomenologi, Konsepsi, Pedoman, dan Contoh Penelitian. Bandung: Widya Padjadjaran.

Lindlof, Thomas R., 1995. Qulitative Communication Research Methods. Thousand Oaks, London: Routledge.

Moleong, Lexy J., 2006. Metodologi Penelitian Kualitatif. Bandung: Remaja Rosdakarya.

Mulkhan, Abdul Munir, 1995. Teologi Kebudayaan. Yogyakarta: Pustaka Pelajar.

Mulyana, Deddy dan Solatun, 2007. Metode Penelitian Komunikasi. Bandung: Rosda. 
Mulyana, Deddy, 2001. Metodologi Penelitian Kualitatif. Paradigma Baru IImu Komunikasi dan IImu Sosial Lainnya. Bandung: Rosda.

Nasution, Harun, 1992. Membumikan Al-Qur'an. Bandung: Mizan.

Nasution, Harun, 1995. Islam Rasional. Bandung: Mizan.

Nasution, S., 1996.Metodologi Penelitian Naturalistik Kualitatif. Bandung: Tarsito.

Pace, R. wayne\& Don F. Faules, 2001. Komunikasi Organisasi. Bandung: Rosda.

Pawito, 2007.Penelitian Komunikasi Kualitatif. Yogyakarta: LKiS.

Rumanti, Maria Assumpta, 2002. Dasar-Dasar Public Relation, Teori dan Praktik. Jakarta: Grasindo.

Santana, Septiawan, 2010. Menulis IImiah: Metodologi Penelitian Kualitatif. Jakarta: Obor.

Setyodarmodjo, Soenarko, 2003. Public Relations. Surabaya: Papyrus.

Shihab, M. Quraish, 1992. Membumikan Al-Qur'an. Bandung: Mizan.

Suprayogo, Imam dan Tobroni, 2001. Metodologi Penelitian Sosial-Agama. Bandung: Remaja Rosdakarya.

[1] MEA, a new breakthrough bwhere free trade between ASEAN countries is officially adopted. In English, MEA is known as the ASEAN Economic Community (AEC), where AEC or MEA is prepared to realize ASEAN 2020 insight integration.Of course, the ASEAN economic community has been agreed upon by all ASEAN member countries. See http: // blogpengertian . com / mea-is-an-economy-asean society /

[2] Article 29 of the 1945 Constitution which affirms that the state is based on the Godhead and the state guarantees the independence of each resident to embrace his own religion and to worship according to his religion and belief.

[3] Mulyana, Metodologi Penelitian Kualitatif, 2001, p.148

[4] Moleong, Metodologi Penelitian Kualitatif, 2006, p.247

[5] Data obtained through in-depth interviews with several informants.

[6] Data obtained through in-depth interviews

[7] Data obtained through in-depth interviews

[8] Data obtained through in-depth interviews

[9] Data obtained through in-depth interviews

[10] Data obtained through in-depth interviews

[11] Data obtained through in-depth interviews

[12] Data obtained through in-depth interviews

[13] Data obtained through in-depth interviews 